Chirurgia (2018) 113: 137-143

No. 1, January - February

Copyright@ Celsius

http://dx.doi.org/10.21614/chirurgia.113.1.137

\title{
Laparogastroscopy and Esophageal Stenosis
}

\author{
Alexandru-Dan Sabău', Noor Hassan', Cătălin Gabriel Smarandache², Alin Mihețiu', Ștefan Țîțư ${ }^{3}$, Dan Sabău' \\ 1"Lucian Blaga" University of Sibiu, Clinical Emergency County Hospital, Sibiu, Romania \\ 2"Carol Davila" University of Medicine and Pharmacy, Bucharest, Romania \\ 3“Iuliu Hațieganu” University of Medicine and Pharmacy, Cluj Napoca, Romania
}

Corresponding author:

Alexandru-Dan Sabău, MD

1"Lucian Blaga" University of Sibiu

Clinical Emergency County Hospital

Sibiu, Romania

E-mail: alx_sabau@yahoo.com
Received: 30.12 .2017

Accepted: 02.02.2018

\section{Rezumat}

\section{Laparogastroscopia și endoprotezarea esofagiană}

Scop: Tehnică originală ce utilizează instrumentar laparoscopic într-o cameră de lucru endocavitară gastrică cu potențial de abord al stomacului, esofagului şi D1. Principalul scop al laparogastroscopiei este îmbunătățirea calității vieții pacientului dezabilitat de tumora esofagiană. Această metodă prezintă multiple avantaje: asigurarea alimentării fiziologice, recoltarea materialelor pentru examenul histopatologic, rezolvarea fistulelor eso-traheale concomitent cu operația propusă, rol hemostatic prin compresiune, consum energetic şi plastic redus, reintegrare socio-economică rapidă, menajarea psihică a pacientului. Această metodă creşte durata de supraviețuiere printr-un regim relativ normal.

Material şi metodă: Lucrarea vizează 162 de cazuri cu localizări diferite ale tumorii esofagiene, pacienți cu diferite grade ale stenozei esofagiene, stadii diferite ale neoplasmului esofagian. Au fost incluşi atât pacienții cu fistule eso-traheale cât şi cei care s-au prezentat cu gastro- sau jejunostomă de alimentație.

Rezultate: Din 162 de cazuri, 33 de cazuri (20\%) cu neoplasm esofagian cervical, 66 (41\%) de cazuri cu neoplasm esofagian toracic şi $63(39 \%)$ de cazuri cu neoplasm esofagian abdominal. Tipul histopatologic este reprezentat de 37\% adenocarcinoame şi $63 \%$ carcinoame scuamoase. Din numărul total de cazuri, 87 (54\%) nu au prezentat metastaze, iar $75(46 \%)$ au avut determinări secundare. Cea mai frecevntă localizare a metastazelor este a fost la nivel pulmonar, urmată de hepatic (Fig. 1) şi osos. Analiza acestei intervenții a demonstrat că s-au înregistrat complicații mult mai reduse atât din punctul de vedere numeric cât şi al gravității lor, se asigură o durată mai lungă de supraviețuire cu un indice de satisfactie mult mai mare. 
Concluzie: Endoprotezarea esofagiană (EPE) prin abord laparogastroscopic ar trebui să fie o procedura de rezervă în locul unei gastrostomii sau jejunostomii invalidante. EPE este o procedură extrem de eficientă inclusiv prin păstrarea fiziologiei bolului alimentar. Abordul este unul minim invaziv cu atac minim asupra organismului cu reduceri plastice şi estetice semnificative. Această procedură permite vizualizarea protezei atât în timpul stentării cât şi după pentru a verificarea poziției corecte a acesteia.

Cuvinte cheie: endoprotezare esofagiană, laparo-gastroscopie

\begin{abstract}
Purpose: An original technique using laparoscopic instruments in a gastric endocavitary work chamber with potential for esophagus, stomach and D1 vizualisation. The main purpose of laparagastroscopy is to improve the quality of life of the patient disabling by the esophageal tumor. This method has several advantages: providing physiological feeding, harvesting materials for histopathological examination, solving eso-tracheal fistulas concurrently with the proposed operation and hemostatic role through compression, low energy and plastic consumption, rapid socio-economic reintegration, mental psychological care of the patient.

Patients and Methods: The paper deals with 162 cases with different tumors of the esophagus, patients with different grades of esophageal stenosis, different stages of esophageal neoplasm. Both the patients with eso-tracheal fistulas and those with gastro- or jejunostoma were included.

Results: From 162 cases, 33 cases (20\%) with cervical esophageal neoplasm, 66 (41\%) cases with thoracic esophageal neoplasm and $63(39 \%)$ cases with abdominal esophageal neoplasm. The histopathological type is $37 \%$ adenocarcinomas and $63 \%$ squamous carcinomas. From total number of cases, $87(54 \%)$ had no metastasis, and $75(46 \%)$ had secondary determinations. The most frequent localization of metastasis was pulmonary, followed by liver (Fig. 1) and bone. The analysis of this intervention has shown that complications have been much lower both in terms of their numerical value and their severity, a longer survival time with a much higher satisfaction index is ensured.

Conclusion: Esophageal endoprosthesis (EPE) through laparagastroscopic approach should be a a reserve procedure instead of a disabling gastrostomy or jejunostomy. EPE is an extremely effective procedure specially by keeping the physiology of food bowl. The approach is minimally invasive with minimal attack on the body with significant plastic and aesthetic reductions. This procedure allows the prosthesis to be viewed both during and after stenting to check its correct position. This method increases the survival time by keeping a relatively normal regimen
\end{abstract}

Key words: oesophageal endoprosthesis, laparo gastroscopy

\section{Introduction}

Esophageal cancer occupies the $6^{\text {th }}$ place as mortality due to aggressive nature and is steadily increasing, which is why this pathology requires increased attention in diagnostic and treatment modalities. In current practice it is one of the least studied pathologies (1).
The most constant symptom, dysphagia, is also a sign of poor prognosis. Although Romania is one of the countries with a low incidence of esophageal cancer $(1.6$ / 100,000), the diagnosis of the disease is most often at a stage where any therapeutic intention of radicality is a desideratum, most of the time unrealistic. In the majority of cases, we have to treat weakended 


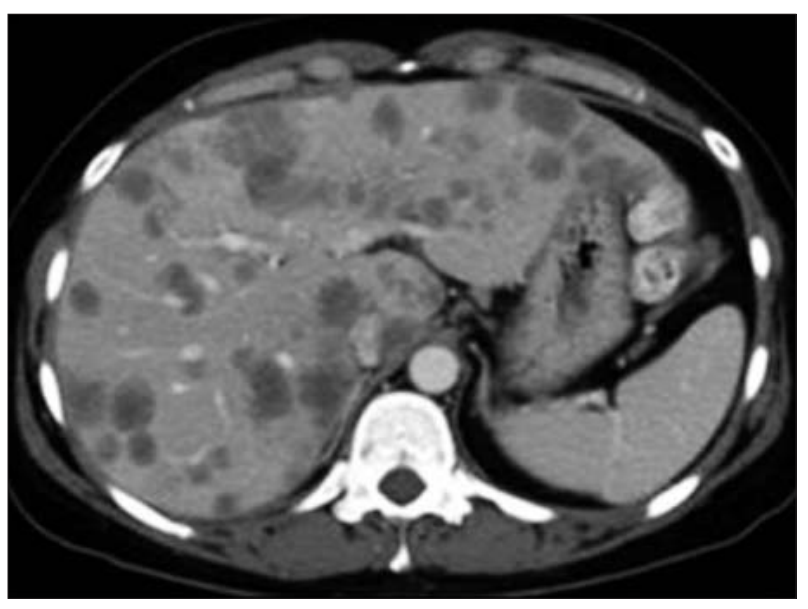

Figure 1. Multiple hepatic metastasis due to esophageal adenocarcinoma

patients, casectic, with poor protein and energy resources with grade 3 or 4 dysphagia (Mellow and Pinkas classification) (2-5).

Esophageal endoprosthesis, a non-invasive solution, is often impossible or endoscopically avoided. Therefore, we thought of a miniinvasive treatment method with minimal attack on the body and preservation of the patient's protein and energy resources. At the same time, the aesthetic substrate and the quality of life were taken into account $(6,7)$.

In esophageal surgery we started with esophageal shunt surgery (colic and gastric, iso and anisoperistaltic), then progressed using esophagectomy, using iso and anisoperistaltic gastric translations or translocations (right and left colon, transverse colon, iso and anisoperistaltic). Late detection and disappointing results in esophageal cancer forced me morally to find an alternative palliative approach. Palliation has meant miniinvasiveness, as a more humanely solution $(6,8)$.

The relatively good results in esophageal stenosis scar surgery, in context of invasive esophagectomy with triple or double approach, led us to attempt reducing miniinvasivity and stent application in these cases as well, mentioning that stenting a scar stenosis is more risky (6).

Esophageal endoprosthesis (Figs. 2, 3) through laparo-gastroscopic approach was thought and used for the first time in 1997 (Prof. Dr. Dan Sabau) and improved over time, after two intentions of stenting in open surgery. This method was also used in patients with
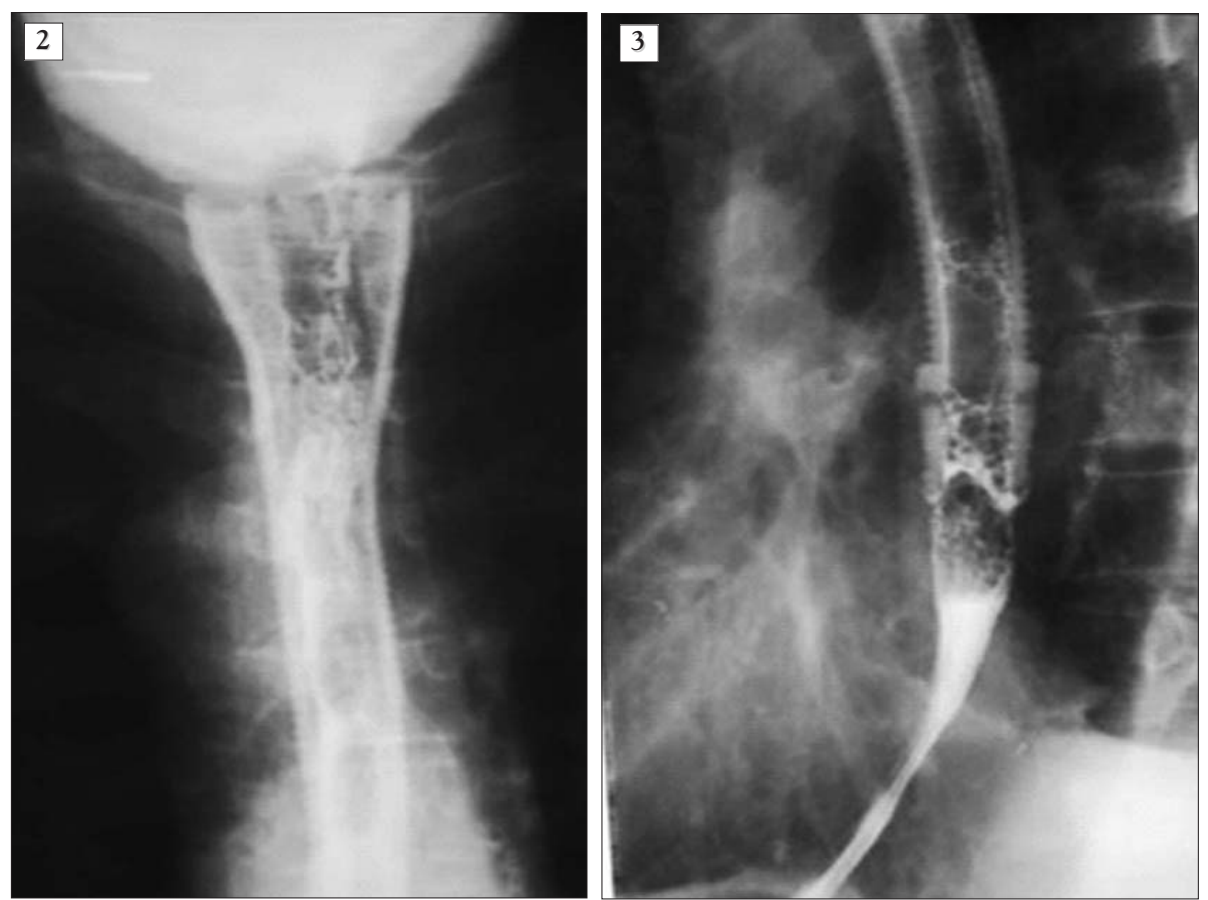

Figures 2, 3. Esophageal prosthesis 
gastric and colorectal neoplasia with questionable results. In the absence of this method, patients can benefit from feeding stomas (gastrostoma, jejunostoma or faringostoma) with the disadvantage of removing the food bowl from the physiological circuit, the patient's dependence on food preparing devicies, depriving patients of food taste, unaesthetic appearance and stoma complications (6).

\section{Description}

The unique method in the world, presented in 2005 at the $6^{\text {th }}$ International Congress of Gastric Cancer in Yokohama where it received the grand prize. The key to success of this intervention is in transtumoral passage with a "blind" catheter or endoscopic catheter insertion (tube, guide wire). In case of failure of the orogastric or guidewire insertion, we performed retrograde, gastro-oral catheterising with different silicone or flexometallic wires, tube with mandrel or plastic stripper. Some tumor formations behave as a flap on the esophageal enterance, not allowing the tube to pass anterograde but just retrograde. Sometimes laparo-gastroscopy has been associated with upper digestive endoscopy with spectacular results (rendez-vous technique) (6).

The prostheses used have been specially developed, especially in pharyngo-esophageal or cardiac locations.

Laparogastroscopy is initiated by making the pneumoperitoneum with the veress needle inserted juxtaombilical and supraombilical (we can also opt for the left iliac fossa or the Palmer point in the case of umbilical hernia or cicatriceal abdomen), inserting the scopic trocar and the telescope with double chambers (Fig. 4) for intraabdominal cavity inventory that can highlight intraabdominal metastases, especially hepatic, diaphragmatic and possible synchronic tumor formations $(6,9)$.

Focusing our attention on the stomach by calculating a suitable angle for making the laparogastroscopy and a facile view of the eso-gastric junction. We prefer an approach on the greater curvature on the anterior face that is marsupialized at left subcostal region on the

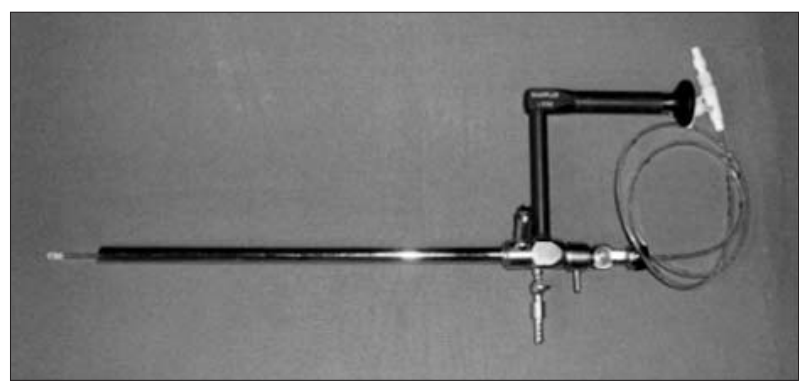

Figure 4. Double chamber telescop

midclavicular line. Minimizing pneumoperitoneum we will reduce tension in the gastric wall. Introducing a scoping trocar and telescope with double chamber in the stomach can lead us to starting our exploration. Gastro-esoscopy will be performed using the rigid telescope through which we can visualize mid or lower oesophageal tumor formations and taking biopsies as well. sometimes we can ascend the area of vision by inserting a long telescope $(40 \mathrm{~cm})$ with a diameter of $5 \mathrm{~mm}$ through the inserted telescope. We will fix the tip of orogastric tube outside of the left subcostal minim incision. At the proximal site of the orogastric tube, an endoprosthesis system consisting of increasing diameter tubes will be installed up to the distal edge of the prosthesis. Cranio-caudal traction of the tubes (Fig. 5) will be carried out, which leads to the installation of the prosthesis in the tumor area. After dilatation or transstenosis drilling, we prefer silicone semi-plastic stents, con-like or with distal plateau, that autoblocks in proximal site of the tumor $(6,10,11)$.

In the case of upper tumors, the prosthesis is fixed to retropharynx (Fig. 6), and in case of inferior tumors we used prosthesis with antireflux device. The gastro-oral hydro-pneumo passage or liquid passage is a good sign of the permeability of the prosthesis and the confirmation of its placement in the tumor area, also by laparo-gastroscopy we can visualize the prosthesis and its permeability. Also, in the case of upper endoprosthesis, we have used the mobile endoscope and the laryngoscope with display to visualize the hypopharynx or even the rigid telescope as an esophagoscope $(6,10)$. 


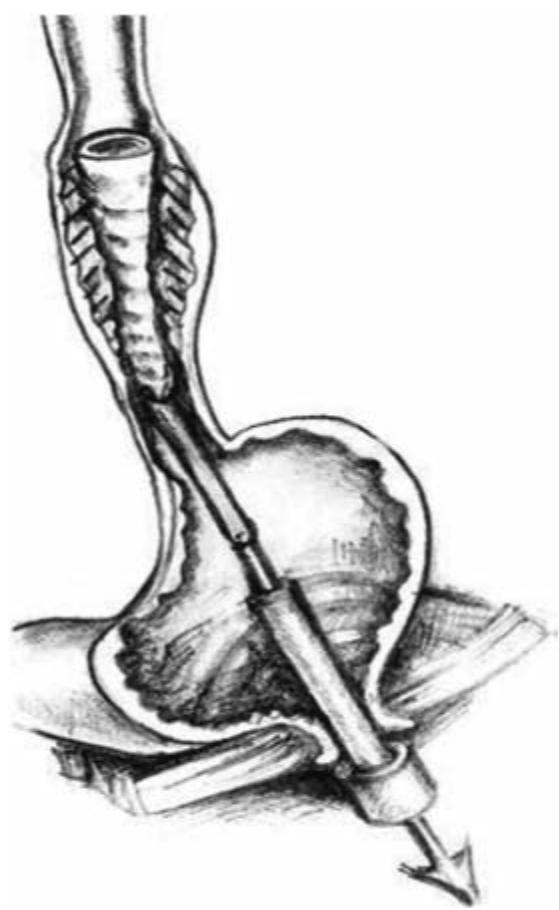

Figure 5. Esophageal stenting by transtumoral drilling

Subsequently, after fixation into the stenotic area, the internal prosthesis that is fixed with a wire at the proximal end is extracted through the oral cavity. After the gastroraphy, we consider fitting a drain tube near the gastrorafia. This method of esophageal stenosis does

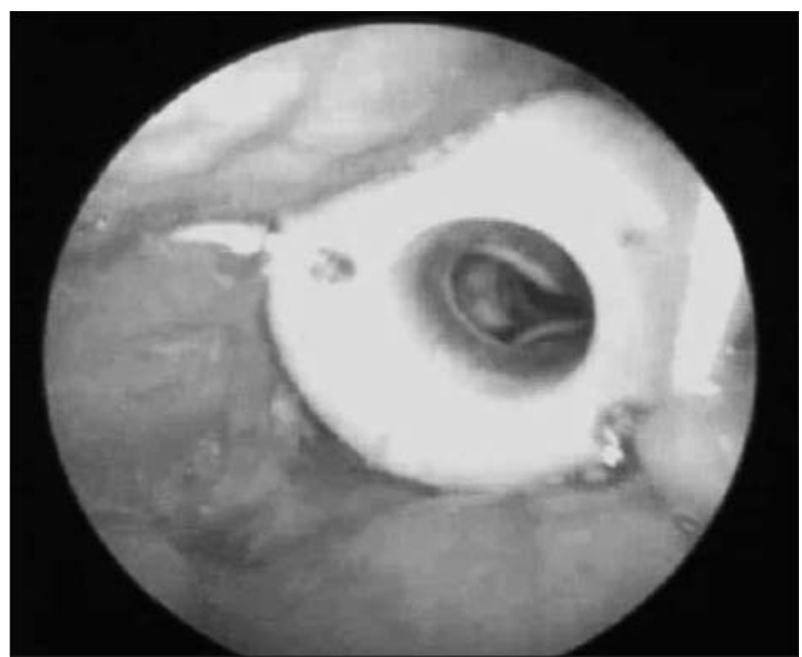

Figure 6. Retropharynx fixation of prosthesis

not require food abstinence; the prosthesis is checked immediately after waking the patient with some liquid, and from the first day the patient is allowed to consume liquid and semiliquid products. After 3-5 days post operative he can consume solid foods (well chewed) $(12,13)$.

To prevent obstruction of the prosthesis, preprandial a teaspoon of olive oil (lubrifiant effect) is recommended and a carbogazeous drink (piston effect) to clean the prosthesis postprandial (6).

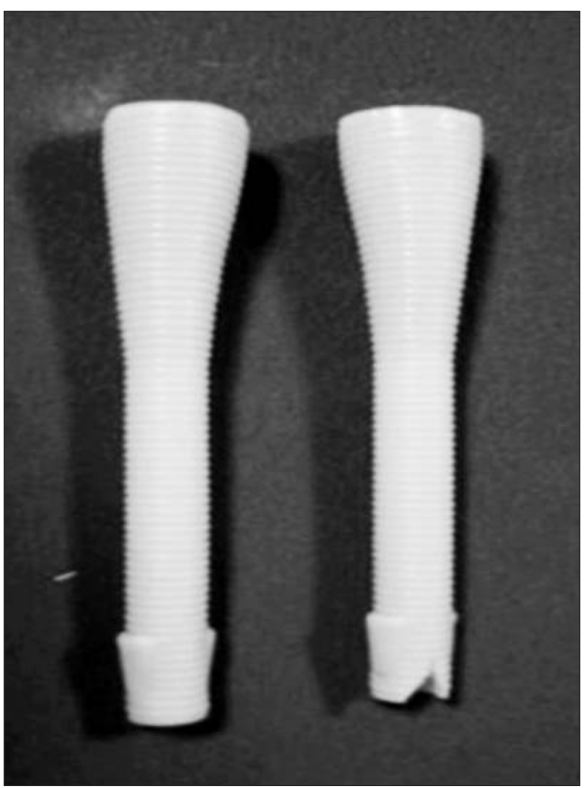

Figure 7. Plastic prosthesis

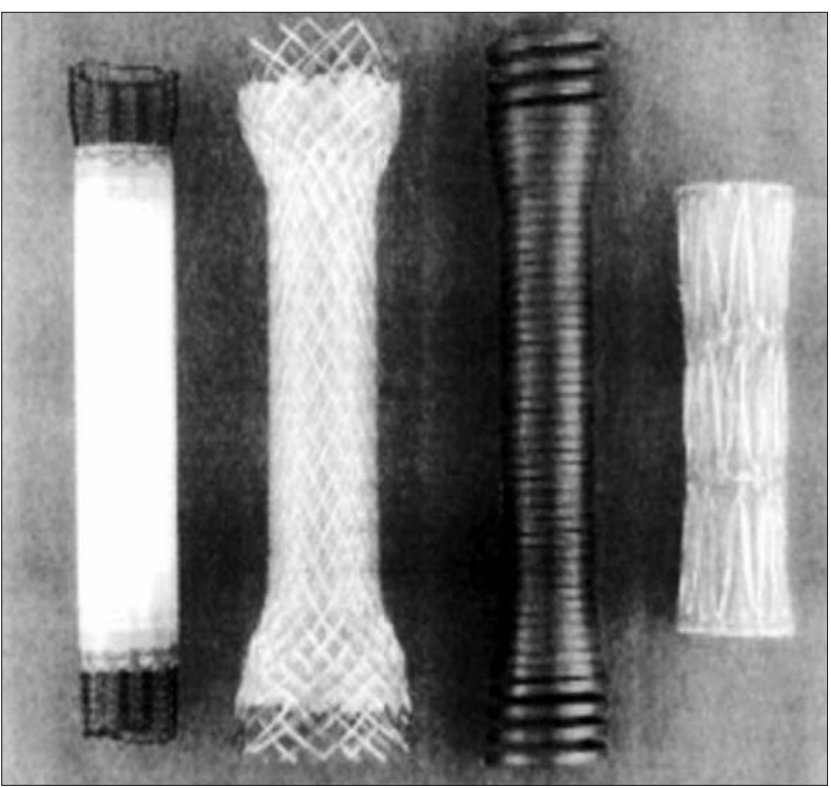

Figure 8. Flexometalic prosthesis 


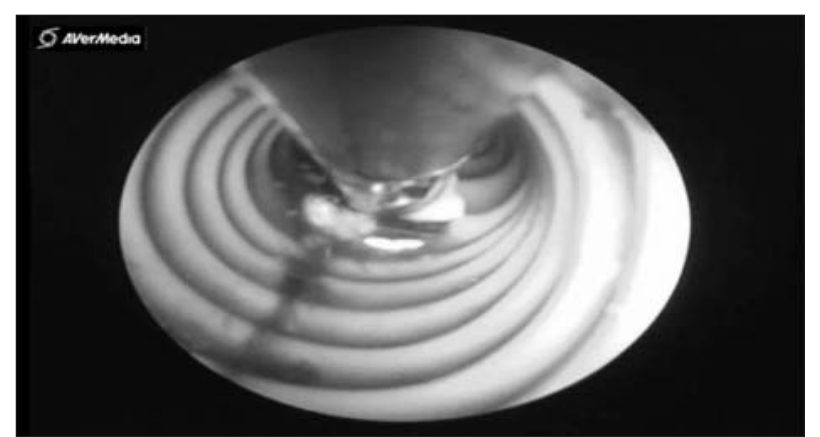

Figure 9. Endoscopic aspect of a silicone prosthesis

We also used this method in patients with eso-tracheal, tumoral or postoperative fistula, using silicone personalized prostheses with very good results (Fig. 10) (8,14). Esophageal endoprosthesis in the case of eso-tracheal fistula is extremely difficult (15-17).

\section{Complications}

A problem we faced with large tumors and cartilage-like tumors was the internal denting of the prosthesis due to extrinsic compression. For this inconvenience, initially we intended the recalibration of the prosthesis by dilatation using the Foley tube, but the results were not so satisfying, in most cases we have recourse to instrumental dilatations of the dentured prosthesis. By going through the learning curve, we used the "prosthesis in the prosthesis" method with the best results. The internal prosthesis (mandrel) strengthening the external prosthesis wall during the traction, not letting the external stent to be squeezed and kept the lumen open (18).

In the case of failure, very rarely (one case in 3 years), we have recourse to feeding stomas, especially pharyngotoma, considering that this is the most resistant compared with gastro or jejunostomas (12).

\section{Conclusions}

- We had outstanding results in most situations, the most important being the conservation of oral nutrition.

- The laparo-gastroscopic installation of

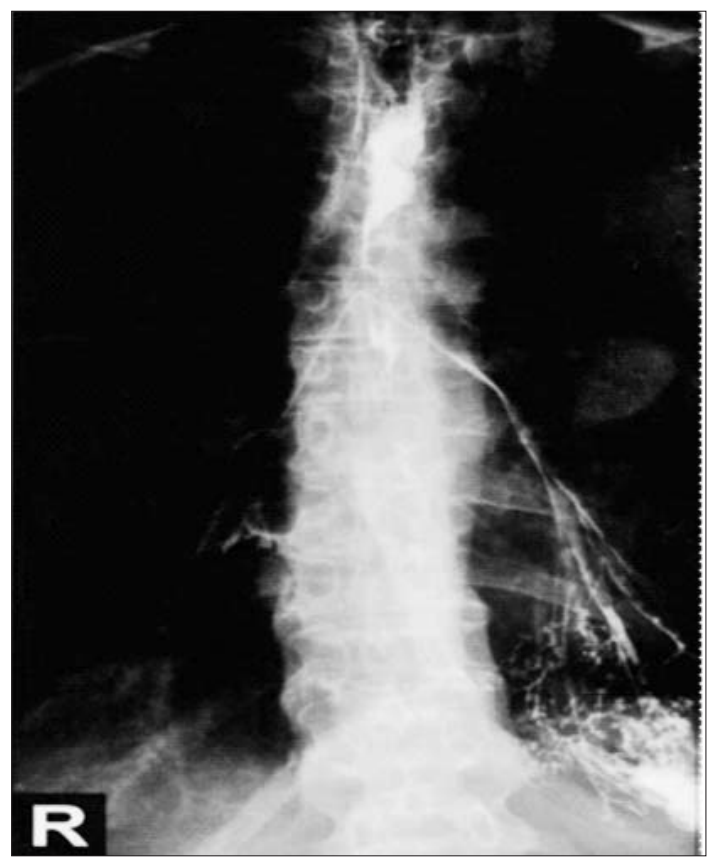

Figure 10. Fistula

esophageal prosthesis as a reserve procedure for endoscopic fails and an additional solution for digestive stomas.

- Laparogastroscopy significantly increases the number of cases with endoprosthesis and ensures the comfort of oral versus stomach nutrition.

- We recomand this method of endoprothesis not just for esophageal cancer but for many other pathologies such as cancer affecting cavitary oragns, benign esophageal stenosis, cicatricial stenosis and history of gastro-esophagectomy .

- Esophageal stenting useing personalized silicon prothesis can be a suitable treatment for eso-tracheal fistula.

- This method increases the survival time by keeping a relatively normal regimen.

- Ensures the physiological nutrition of the patient through a minimal attack on the body and maintenance of the proteinenergy resources.

- Leads to an increase in the patient's satisfaction rate.

- The possibility of harvesting materials for primary or secondary histopathological examination. 

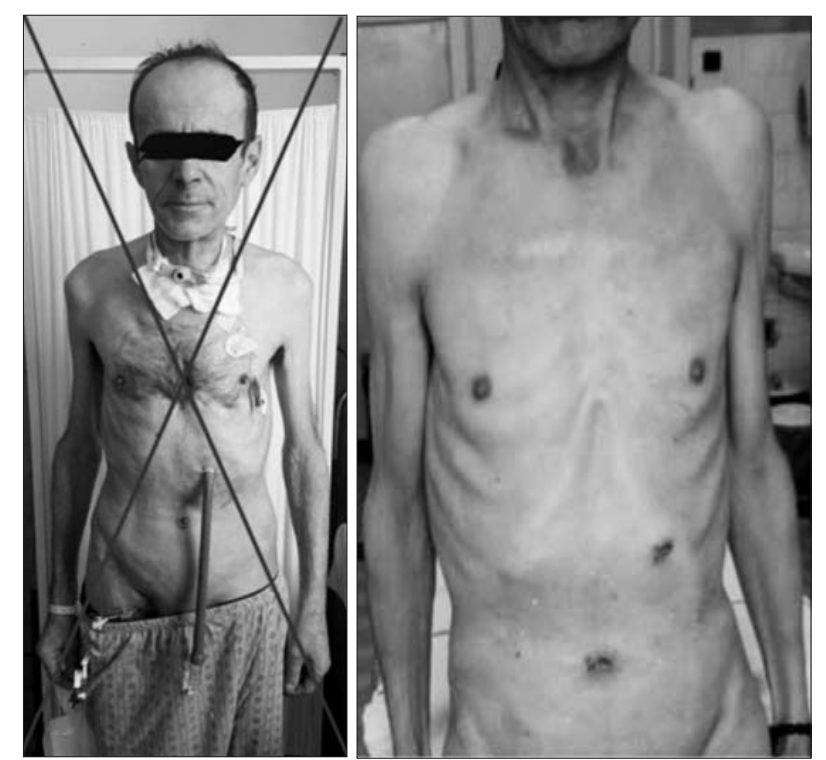

Figure 11. Gastrostomy Figure 12. Postoperative and tracheostomy

- gives us the opportunity to visualize the proximal portion of the duodenum, stomach and esophagus.

- rare postoperative complications.

- In conjunction with superior digestive endoscopy (rendez-vous technique), it can lead to stenting in case of inop patients or patients with high difficulty score.

- Laprogastroscopic endoprothesis is a minimally invasive method of choice for patients with oesophageal neoplasm and not only, requiring palliative surgery.

\section{References}

1. Brown LM, Devesa SS, Chow WH. Incidence of adenocarcinoma of the esophagus among white Americans by sex, stage, and age. J Natl Cancer Inst. 2008;100(16):1184-7.

2. Siewert JR, Stein HJ. Classification of adenocarcinoma of the oesophagogastric junction. Br J Surg. 1998;85(11):1457-9.
3. Edge SB, Byrd DR, Compton CC et al, eds. Esophagus and esophagastric junction. In AJCC Cancer Staging Manual. 7 ed. New York: Springer-Verlag; 2010. p. 103-15.

4. Rice TW, Blackstone EH, Rusch VW. A cancer staging primer: esophagus and esophagogastric junction. Thorac Cardiovasc Surg. 2010;139(3):527-9.

5. Cordin J, Lehmann K, Schneider PM. Clinical staging of adenocarcinoma of the esophagogastric junction. Recent Results Cancer Res. 2010;182:73-83.

6. Sabău D. Sabău A, Laparogastroscopia si stentarea esofagiană în boli benigne și maligne. In: Constantinoiu S, Tratat de patologie și chirurgie esofagiană. Bucuresti: Editura Academiei Romane; 2017. p. 264 - 274.

7. Devesa SS, Fraumeni JF Jr. The rising incidence of gastric cardia cancer. J Natl Cancer Inst. 1999;91(9):747-9.

8. Dobrucali A, Caglar E. Palliation of malignant esophageal obstruction and fistulas with self expandable metallic stents. World J Gastroenterol. 2010;16(45):5739-45.

9. Sakai M, Sohda M, Miyazaki T, Yoshida T, Kumakura Y, Honjo H, et al. Association of Preoperative Nutritional Status with Prognosis in Patients with Esophageal Cancer Undergoing Salvage Esophagectomy - Anticancer Res. 2018;38(2):933-8.

10. Sabău D, Dumitra A, Sabău A, Smarandache G, Ursache E, Grosu $F$, et al. Esophageal endoprosthesis by laparo-gastroscopy with transtumoral approach in advanced esophageal and esophagogastric cancer. Chirurgia (Bucur). 2009;104(5):545-52.

11. Schmassmann A, Oldendorf MG, Gebbers JO. Changing incidence of gastric and oesophageal cancer subtypes in central Switzerland between 1982 and 2007. Eur J Epidemiol. 2009;24(10):603-9.

12. Hulpus R, Constantinoiu S, Bratu D, Dumitra A, Sabau A, Ursache $\mathrm{E}$, et al. Superior socio-medical alternative to feeding gastrostomy and jejunostomy in advanced esophago-gastric junction adenocarcinoma. Chirurgia (Bucur)108: 451-455.

13. Melhado RE, Alderson D, Tucker 0 . The Changing Face of Esophageal Cancer Cancers. Cancers (Basel). 2010 Jun 28;2(3):1379-404. doi: 10.3390/cancers2031379.

14. Miyata $T$, Watanabe M, Nagai $Y$, Iwatsuki M, Iwagami S, Baba $Y$, et al. Successful esophageal bypass surgery in a patient with a large tracheoesophageal fistula following endotracheal stenting and chemoradiotherapy for advanced esophageal cancer: case report. Esophagus. 2013;10(1):27-29. Epub 2012 Jul 19.

15. Constantinoiu S, Bîrlă R. Adenocarcinomul de joncțiune esogastrică. În: Popescu I, Tratat de Chirurgie, Vol VIII partea IB. București: Editura Academiei Române; 2008. p. 1228-1247.

16. Burt M, Diehl W, Martini N, Bains MS, Ginsberg RJ, McCormack PM, et al. Malignant esophagorespiratory fistula: management options and survival. Ann Thorac Surg. 1991;52(6):1222-8; discussion 1228-9.

17. Stemerman DH, Caroline DF, Dabezies M, Mercader VP, Krevsky B, Gatenby RA. Nonexpandable silicone esophageal stents for treatment of malignant tracheoesophageal fistulas: complications and radiographic appearances. Abdom Imaging. 1997;22(1):14-9.

18. Dumitra A, Sabău A, Maniu D, Grosu F, Smarandache G, Ursache E, et al. Particular aspects of endoprosthesis in malignant advanced pharingeal-esophageal stenosis. Chirurgia (Bucur). 2011;106(3): 327-32. Romanian 